\title{
Renewable energy, trade performance and the conditional role of finance and institutional capacity in sub-Sahara African countries
}

\author{
Akinyemi Opeyemi $^{\mathrm{a}}$, Efobi Uchenna ${ }^{\mathrm{b}, *}$, Asongu Simplice ${ }^{\mathrm{c}}$, Osabuohein Evans ${ }^{\mathrm{d}}$ \\ ${ }^{a}$ Department of Economics and Development Studies, \& Centre for Economic Policy and Development Research (CEPDeR), Covenant University, Ota, Nigeria \\ ${ }^{\mathrm{b}}$ College of Business and Social Sciences, \& Centre for Economic Policy and Development Research (CEPDeR), Covenant University, Ota, Nigeria \\ ${ }^{\mathrm{c}}$ Department of Economics, University of South Africa, P. O. Box 392, UNISA, 0003, Pretoria, South Africa \\ ${ }^{\mathrm{d}}$ Centre for Economic Policy and Development Research (CEPDeR), Covenant University, Ota, Nigeria
}

\section{A R T I C L E I N F O}

\section{Keywords:}

Environment

Green growth

Trade performance

Pollution

Renewable energy

Sub-saharan africaJEL Code:

C5

F1

Q4

Q5

\begin{abstract}
A B S T R A C T
The paper investigates the dynamic relationship between renewable energy usage and trade performance in subSaharan Africa (SSA), while considering the conditioning role of corruption control, regulatory quality, and the private sector access to finance. Focusing on 42 SSA countries for the period 2004-2016, and engaging the System generalized method of moments (GMM) technique for its estimation, this study found a negative relationship between renewable energy usage and the indicators of trade performance. However, with corruption control, improved regulatory framework, and better finance for the private sector, there are potentials for a positive net impact of renewable energy usage on manufacturing export. For renewable energy and total trade nexus, we find that improved regulatory framework, and better finance for the private sector are important conditioning structures. These findings are significant because they highlight the different important structures of SSA countries that improves the effect of renewable energy use on trade outcomes. For instance, the consideration of the financial, institutional and regulatory frameworks in SSA countries in conditioning the renewable energy-trade nexus stipulates a clear policy pathway for countries in this region as the debate for transition to the use of renewable energy progresses.
\end{abstract}

\section{Introduction}

The realization that current production and consumption patterns that are not environmentally friendly - in terms of pollution - coupled with high economic dependencies of developing countries on primary export, which increases environmental risks, has further reinforced the increasing attention on the importance of transitioning to renewable energy usage for development (Njoh et al., 2019; Rezaee et al., 2019). Such development is expected to result in economic progress and environmental sustainability, which is consistent with Amavilah et al. (2017)'s argument for inclusiveness and sustainability in the growth trajectory of African countries.

A number of countries, including those in sub-Saharan Africa (SSA), have made some commitment through the signing of international agreements (e.g. Paris Climate Agreement) to lower carbon emission levels and adopt efficient production processes that minimize environmental risks. However, this has been difficult to implement, and progress towards the implementation of such agreements has remained sluggish due to growing economic prosperity of SSA is connected with primary products extraction, which increases environmental pollution and other forms of emission (Akinyemi et al., 2017; Asongu et al., 2017; Njoh et al., 2019; Obeng-Darko, 2019). Therefore, managing this tradeoff between environmental sustainability and economic progress has remained a challenge in SSA.

This paper contributes to this policy discussion by adopting a unique approach that rely on the data from the World Bank World Development Indicators, and other sources to estimate the direct relationship between renewable energy usage and two trade outcomes (total trade and manufacturing export) of SSA countries. The data also allows for the exploration of the conditioning effect of institutional structure (control of corruption), regulatory quality, and private sector access to finance on the nexus. As such, the analysis of this paper advances the proposition that although the transition to renewable energy use may be costly on SSA's trade outcomes, such costs can be significantly reduced with the improvement of these structures.

This inquiry is important for the following reasons. First, the

\footnotetext{
* Corresponding author.

E-mail addresses: opeyemi.akinyemi@covenantuniversity.edu.ng (A. Opeyemi), uche.efobi@covenantuniversity.edu.ng (E. Uchenna), asongusimplice@yahoo.com (A. Simplice), evans.osabuohien@covenantuniversity.edu.ng (O. Evans).
} 